\title{
Childhood health and social class reproduction in China
}

\author{
Yanbi Hong ${ }^{1,2^{*}}$ and Jingming Liu $^{3}$
}

\section{${ }^{*}$ Correspondence:}

hongyb@seu.edu.cn

${ }^{1}$ Department of Sociology,

School of Humanities,

Southeast University, Nanjing,

China

Full list of author information

is available at the end of the

article

\begin{abstract}
In previous studies on social stratification and mobility in China, education is considered as the core mediatory factor in social reproduction and mobility. This paper, however, investigates how childhood health affects social stratification. Using data from Urbanization and Labor Migrant National Survey (2012), this study examines the effects of nutrition, hygiene, and health before age 14 on adult socioeconomic status attainment, including education, the international socioeconomic indexes of first job and current job, and family income per head. The structural equation model results show that the nutrition intake (whether one experienced starvation and the frequency of fish and meat intake) and hygiene (indicated by the source of drinking water and the toilet type) have significant effect on adult socioeconomic status attainment. However, the effects change at different life course stages. Moreover, childhood health (indicated by adult height) has significant impact on adult socioeconomic status attainment, but no significant impact on the international socioeconomic indexes of first job and current job. We conclude that investment in childhood health is an important mechanism affecting social class reproduction and mobility. Therefore, health intervention for children from poor and disadvantaged families are necessary. It will benefit children's education and encourage upward mobility.
\end{abstract}

Keywords: Childhood health, Childhood nutrition and hygiene, Heights, Social reproduction

\section{Introduction}

...that the health and nutrition of one generation contributes, through mothers and through infant and childhood experience, to the strength, health and longevity of the next generation; at the same time, increased health and longevity enable the members of that next generation to work harder and longer to create the resources which can then, in their turn, be used to assist the next, and succeeding, generations to prosper.

Fogel and Grotte (2011)

Social class crystallization is a topic that has attracted much attention from the academia. Based on the existing research on social mobility, Hout (2015) pointed out that future research should focus on how childhood living condition and environment author(s) and the source, provide a link to the Creative Commons licence, and indicate if changes were made. The images or other third party material in this article are included in the article's Creative Commons licence, unless indicated otherwise in a credit line to the material. If material is not included in the article's Creative Commons licence and your intended use is not permitted by statutory regulation or exceeds the permitted use, you will need to obtain permission directly from the copyright holder. To view a copy of this licence, visit http:// creativecommons.org/licenses/by/4.0/. 
impact the prospect of adulthood, rather than only examining who can gain upward social mobility. Here, "childhood living condition" is a multidimensional and holistic concept. In China, current research on social stratification and mobility mainly focuses on the role of education in social reproduction. This article, instead, focuses on the role of another key factor, childhood health. Examining childhood health can enhance our understanding of social stratification, intergenerational reproduction of inequality, and determinants of earnings and income (Palloni 2006). Unlike in the West, in the Chinese academia the impacts of childhood health on human development and social reproduction remain a highly unexplored area (Sun and Peng 2014). Using retrospective studies and data of heights, this research analyzes the impacts of childhood nutrition, hygiene, and health on adult socioeconomic status (SES) attainment. Two questions will be addressed: First, how does family background impact childhood nutrition, hygiene, and health? And second, do childhood nutrition, hygiene and health have impacts on adult SES? This article is organized as follows: Section one will review the existing literature, discuss the long-term impacts of childhood health and determinants, and propose several hypotheses accordingly. Section two will describe the data, variables and models used in this research. Section three will examine the effects of childhood nutrition, hygiene, and health in the intergenerational transmission of SES. Finally, Secton four will summarize and discuss the findings.

\section{Backgrounds: influencing factors and long-terms impacts of childhood health Mechanisms of social stratification: education and health}

Various pathways exist between family background variables (parental characteristics) and the variables related to child outcomes. These pathways can be classified into two groups: (1) direct pathways: parents influence their children's SES by directly passing on resources to the latter. An unequal power structure, for example, allows those holding redistributive power to transfer resources directly to their offspring through rentseeking behaviors (Chen 2010; Liu 2018). The social capital possessed by different social classes vary, which will influence the next generation's career advancement. (2) Indirect pathways: parents' resources influence children's SES, but the influence has to be mediated by children's attributes, such as education, health, etc. ${ }^{1}$ Past research on indirect pathways to social stratification mainly focuses on the role of education, whereas the role of childhood health has not been adequately discussed (Currie 2009). Numerous economic and public health studies have revealed that health, in particular childhood health, have significant impacts on adulthood health condition and SES (Case and Paxson 2008; Campbell et al. 2014; Basu 2015). It has been reported that some rural areas in China face severe challenges of infant nutrition and health. For instance, in a 2013 survey on 1808 infants from 351 villages in several impoverished counties in south Shaanxi Province, $48.8 \%$ of the infants suffered anemia, 20\% experienced cognitive developmental delays, and 32.3\% were delayed in their psychomotor development (Luo et al. 2015). These childhood health problems not only affect children's academic performance and education attainment (Wang et al. 2016), but also will have long-term impacts on their

${ }^{1}$ Due to the existence of indirect pathways, high social status will not automatically or entirely benefit those who are born to it (see Bourdieu and Passeron 2002: 33). 
adulthood SES (Almond et al. 2010). In other words, poor childhood health may have already compromised the prospect of their adult life. However, the role of childhood health in social stratification and social mobility has not been adequately discussed in China, primarily because of the neglect from existing theories.

First, in existing research on social stratification and social mobility, education has been viewed as the main mediating factor. The classic Blau-Duncan model distinguished ascriptive characteristics and achieved characteristics, highlighting the key role of child's education (achieved characteristic variable) in intergenerational transmission of SES (Blau and Duncan 1967; Zhou 2009). Based on the Blau-Duncan model, the Wisconsin model further studied and underscored the impacts of educational expectation and influences of significant others (Sewell et al. 2001). The current research on social stratification and social mobility in China still follows the Blau-Duncan model (Li and Zhu 2015); as a result, social stratification research in the country predominantly focuses on educational stratification. Of course, there is no doubt that education consists in an important factor in SES attainment in modern society, and a social resource that members of a society actively pursue and compete for (Treiman and Yip 1989; Xu 2017). Studies have found that education inequality in China has worsened, despite the expansion of education system (Hao 2007; Li 2014). The worst educational stratification is found in the period of primary and junior secondary education (Wu 2013; Tang 2015). Scholars are increasingly aware of the importance of early educational inequality, but most research on the topic focuses on the different forms of capital possessed by family, or parents' educational practice. Based on the CFPS2010 data, Yu Xie and his colleagues found significant correlations between family's economic condition and children's skill acquisition. Paradoxically, this research also found that although the main pathway is through non-material resources such as educational practice, educational practice per se is not influenced by economic condition (Liu and Xie 2015). Studies abroad found that family's socioeconomic condition during one's early childhood has important influence on his/her educational attainment, and this effect is greater than that of socioeconomic condition during one's middle childhood (Duncan et al. 1998; Case et al. 2002). That being said, it remains unclear the pathways through which socioeconomic condition affects children's skill acquisition and educational attainment (Currie 2009). Besides the diverse forms of capital or upbringing, we believe childhood health could be another key to open this black box.

Second, past research on social stratification did not pay enough attention to the individuals' ascriptive statuses (including childhood health) prior to entering the educational system. Instead, they are often treated as control variables. On one hand, sociologists tend to assume that individual differences are none or negligible upon birth, which has been strongly challenged by sociologists of genetics. This group of scholars argue that the outcomes of the influence of social factors on individuals depend on specific genetic types and the nature of the social factors ( $\mathrm{Hu}$ et al. 2012). On the other hand, when researchers of stratification study ascriptive factors, they tend to look into parental SES (such as in the Blau-Duncan model) and treat predetermined factors that influence 
individual educational or job attainment rather as disturbance variables, as they believe that individuals are born with certain "capability", intelligence, or genes. ${ }^{2}$ Although genetic influences are not negligible, the genetic influences that have been identified can only explain a small proportion of human diversity (Currie 2011). A larger proportion of the variation is attributable to social factors. There is no definitive conclusion on to what extent so-called IQ and talent are genetic factors. Previous research concluded that genetic factors can only explain $23 \%$ of the variation in educational attainment, whereas family factors can explain $41 \%$ (Nielsen and Roos 2015). In addition, the influence of genetic factors is also mediated by environmental factors; whether the impacts of genetic factors are triggered depend on socio-environmental factors. In a beneficial environment, negative genetic influences may not be triggered on infants. Therefore, childhood health is the outcome of the combination of genetic propositions and family background/ resources. Further research is needed to understand the complexity of the mechanisms.

Third, although sociologists in China pay increasing attention to health-related research, existing research tends to focus on the influence of social background on health outcomes (Wang 2011, 2012, 2017; Jiao 2014) but somehow overlooks the impacts of the stratification in childhood health on social stratification and social mobility. Bulk of the health-related research debates on the social causation theory and the health selection theory. The former views socioeconomic inequality as the fundamental cause of health inequality (Warren 2009; Bird et al. 2010); and education is believed to be the key determinant of health outcome, among the three socioeconomic indicators (occupation, education, and income, see Ross and Mirowsky 2010; Hu 2014; Hong and Chen 2017). Wang (2011)'s research, for example, concludes that intergenerational social mobility has significant impact on children's health outcomes-in other words, health outcomes are viewed as the result of social stratification, rather than an independent variable that can influence the dynamics of stratification. Meanwhile, education is treated as both an independent and a dependent variable. In contrast, the health selection theory underscores the influence of health inequality on the attainment of educational and socioeconomic status (Haas 2006). Economists see education and health as core components of human capital, which can influence economic output (Schultz 1961). Grossman (1972) even proposed the concept "health capital" and framed health as a lasting form of capital stock, which provides healthy working time. Extensive economic research has shown that on one hand, poor health can lead to impoverishment by affecting individuals' job acquisition, income, and wealth accumulation; on the other hand, childhood health may affect cognitive development and the formation of human capital (Haas 2006; Heckman 2007; Cheng et al. 2014). A longitudinal study in UK identified the close relationship between individual height, family social class background, and social mobility, which, according to the researchers, reflects the influence of childhood health on social reproduction (Power et al. 1986). Using birth weight as indicator of childhood health, a research on twins in Norway found that birth weight has significant influence on infant morality, future height, IQ, educational attainment, and income (Black et al. 2007). In

2 This tendency is also driven by researchers' persistent pursuit of causality, as embodied in the recent popularity of propensity score matching analysis. 
China, due to the Great Famine, the cohort born between 1959 and 1961 are more likely to be analphabetic and unemployed than other cohorts. Males from this cohort are more likely to marry late, and females from this cohort are more likely to be married to spouse that have lower educational attainment (Almond et al. 2010).

The disagreement between the social causation theory and the health selection theory centers around their views on the relationship between education and health. Extensive research has tested the relationship between education and health; yet there is no consensus over the causal relationship between them (Grossman 2008). However, if we take a life cycle perspective of health and incorporate health in the discussion of social reproduction and social mobility, it is still possible to reconcile the two theoretical perspectives. Health is both a result and a cause of social stratification. Education influences health, but childhood health can also influence educational attainment and future health. One's health condition also changes in tandem with his or her life trajectory and is determined by both childhood and adulthood living condition (Strauss and Thomas 1998). Therefore, the prevalent analytical framework that places education as the core mediating factor for social stratification and mobility has some flaws. Adding health inequality in the analytical framework can help us to make sense of the contradicting arguments and empirical evidence generated from the two theoretical perspectives, which will also shed light on the dynamics of social stratification and mobility (Palloni 2006; Palloni and Milesi 2006; Haas 2006). In individual's life course, family background influences children's future SES attainment by influencing their early health, which is an important pathway for social reproduction. More specifically, empirical research needs to answer two questions: does parental SES have influence on the childhood health of their children? Does childhood health have influence on adult SES attainment?

Family background and childhood health.

Childhood health is closely associated with the resources and income level of the child's family. This relationship becomes more significant as the child grows up, because many harms resulting from disadvantageous conditions are cumulative (Case et al. 2002). Childhood health is mainly influenced by four factors: material conditions of the family, parents' educational attainment and knowledge, psychological impacts of adverse events, and prenatal health.

First, family resources influence childhood health via medical service, nutrient intake, and living environment (Bradley and Corwyn 2002). Due to material hardship, impoverished families are often unable to provide their offspring with qualified healthcare and adequate safe food. Housing condition is also suboptimal. Nutrient intake is closely related to family economic conditions; insufficient nutrient intake leads to malnutrition, which in turn influences productivity and income (Strauss and Thomas 1998). Thanks to the rapid economic development following China's Economic Reform and Opening Up, the Chinese population has experienced a fast improvement in health, nutrient intake, and life expectance. However, malnutrition still persists in some rural areas and economically undeveloped regions (Almond et al. 2010). Between 1987 and 1992, children's height grew in urban areas as 5 times as fast than in the rural areas, mainly due to the inequality in nutritional adequacy (Shen et al. 1996). For 3-year-old children, their heights and weights are significantly related to whether they receive physical exam, their intake of nutrients, and parenting practice (Wu 2011). Children from some rural 
areas and economically underdeveloped regions show significant disadvantages in these aspects and are more prone to malnutrition (Chen et al. 2006). The major threat the children face in their living environment is hygiene. First, suboptimal hygienic condition can lead to infectious diseases such as flu, malaria, measles, and diarrhea. Although infectious diseases are in general under control in developed countries, yet children from low-income families are still more likely to suffer from asthma, as well as dental and hearing problems (Currie 2009). In developing countries, diarrhea caused by inferior hygienic conditions and diseases is an important threat to the healthy growth of infants (Lutter et al. 1992). In addition, unhygienic living conditions expose children to toxic substance, including air pollution, lead poisoning, and unsafe food. Children from low-income families in these countries are particularly likely to become victims of these hazards (Currie et al. 2010; Gundersen and Kreider 2009). Living in contaminated areas or drinking from well instead of collective supply of water expose individuals to pollution of heavy metal (Zou et al. 2008).

Second, due to their low educational attainment, parents in low-income families often lack knowledge on healthcare and parenting, which may affect their children's health (Currie and Goodman 2010). Surveys have shown that in some rural areas in China, caregivers' lack of knowledge have posed a serious challenge to infants and children's nutritional adequacy and health (Yue et al. 2016). In India, discrimination against females affects girls' nutrient intake and care, which affects girls' heights and weights (Deaton 2008). Education is considered as a learned effectiveness, which enables individuals to think in logical, rational, and integral manner so that they can develop effective solutions to problems and avoid anxiety and depression (Ross and Mirowsky 2010). Therefore, education not only influences one's own health, but can also impact the health of his/her offspring through parenting practices.

Third, children from low-income families are often more likely to experience negative events, leading to stress, depression, and negative impacts on sociopsychological health (Chen 2004). Fourth, childhood health also reflects prenatal health. Besides genetical factors, prenatal health is also influenced by family's social and economic resources. Research has shown that infants born in impoverished mothers are likely to suffer stunting (Currie and Moretti 2007). Natural disasters such as famine can also lead to increasing stress and malnutrition among mothers (Almond et al. 2010), which will influence the health of their offspring. Therefore, in the early stages of life course, family SES has significant impacts on childhood health, and children born to low-income families are often found in unsatisfactory health state.

\section{Mechanisms through which childhood health exerts influence}

Heckman (2007) proposed that workers' income is mainly determined by their individual capability, including cognitive capability, non-cognitive capability, and health. $\mathrm{He}$ contends that childhood health will influence adulthood health, as well cognitive and non-cognitive capabilities, which will influence adulthood labor supply and productivity, and thus, SES. Poor childhood health leads to low educational attainment and early occurrence of chronical diseases, affecting employment and income (Haas et al. 2011). A study in UK found that adults who suffered chronical disease between age 7 and 16 face higher likelihood of low educational attainment, unemployment, and low income 
(Case et al. 2005). Data from the China Health and Nutrition Survey (CHNS) show that individuals who experienced famine during childhood are significantly disadvantageous in heights and income (Chen and Zhou 2007). Overall childhood health and nutrient intake have significant impacts on adulthood income (He and Yuan 2014). Two pathways are at play in this relationship: first, early life health affects cognitive development and educational attainment, which influences job attainment and income. Second, health in adult life also influences adulthood SES.

A large amount of research conducted under the Blau-Duncan model reveals the important the key role of education in individual SES. Family economic conditions have important influence on children's educational attainment (Duncan et al. 1998; Case et al. 2002). As poverty persists, its negative impacts also accumulate (Smith and Yeung 1998). Childhood health and development have important mediating effects in this process. Family's SES influence children's cerebral cortex development, particularly the zones that influence abilities such as language, reading, action execution, and spatial skills (Noble et al. 2015). Poverty leads to lower preschool abilities, resulting in worse academic performance, failure to enter higher school, low participation in school activities, and even dropping out (Duncan et al. 1998). The malnutrition caused by poverty affects children's cognitive development (Maluccio et al. 2006). Health issues such as auditory, dental and psychological problems will severely affect children's academic performance and educational attainment (Currie and Goodman 2010). A survey conducted in the early years of China's Economic Reform revealed the close correlation between childhood malnutrition and future health/ cognitive development (Jamison 1986). Years later, in China's impoverished rural areas, many children still suffer insufficient intake of micronutrient, anemia, and infectious parasitic diseases, or have vision problems but lack resources to acquire eyeglasses, which poses a severe constraint on their learning potential (Hannum and Zhang 2012; Wang et al. 2016). The China Education Panel Survey (CEPS) data also suggest that better childhood and adolescent health is associated with better exam performance, higher cognitive ability, stronger sense of self-efficacy, and social skills (Liang 2017).

In general, individual educational attainment remains unchanged after reaching certain age. This, however, is not the case of one's health state. Health in one's early life is likely to have impacts on the health state in later life stage. At least three pathways exist between one's childhood health and likelihood of disease in adult life: (1) incubation mode: event in a critical moment can generate long-term risk for disease in later life stages; (2) accumulation mode: advantages and disadvantages accumulate throughout one's life course; and (3) pathway mode: one's health state at the starting point will influence that at the endpoint (Marmot 2004). In his famous Children of the Great Depression, Elder (1999) documented the strong impacts of childhood economic deprivation on health in adult life. Studies based in the US revealed that the variable "family background by age 10" has significant impacts on one's smoking behavior, health state, and obesity by age 30 (Conti and Heckman 2010). The impacts of childhood health are so persistent that it is significantly associated with elderly health and self-care ability (Haas 2008; Pakpahan et al. 2017). Based on a longitudinal cohort study in Canada, Currie and colleagues (2010) concluded that childhood health has impacts on adult SES by affecting health in later life stages, except if the health event is only short-term such as leg fracture 
or open wound. In addition, empirical evidence has shown that childhood psychological health has greater impacts on adulthood educational attainment, job income than other factors such as physical health (Delaney and Smith 2012; Lundborg et al. 2014). In sum, chronical, accumulative factors of health have critical impacts on adulthood SES (Case et al. 2002). Therefore, Palloni (2006) argued that the role of childhood health in adulthood SES acquisition is no less important than other factors that have been widely discussed, such as education.

\section{Research strategies and hypothesis}

A major challenge in childhood health research is the difficulty in collecting interviewees' childhood health data, unless in longitudinal studies. ${ }^{3}$ There are two alternative options: (1) to ask interviewees to recall their childhood health (Smith et al. 2012). Yet, retrospective self-assessment of childhood health is biased (Currie 2009) because it is highly subjective and is subject to collective and systematic bias (Qi 2014). In comparison, retrospective self-assessment of nutrient intake is more objective and reliable, although retrospective bias also exists. (2) to use proxies such as birth weight as indicator of fetal health (Currie and Moretti 2007), or to use height as indicator of childhood health (Shen et al. 1996; Case and Paxson 2008). The advantage of using height as proxy is that it allows objective measurement. Also, adult height is the outcome of childhood height and the growth during childhood and adolescence, and it is influenced by factors such as disease and nutrient intake (Bozzoli et al. 2009). Thus, adult height reflects fairly accurately the socioeconomic and public health condition during interviewee's childhood (Deaton 2008; Smith et al. 2012). Although height is also strongly related to intergenerational transmission, existing research has found that the genetic factor can only explain 5\% of the intergenerational transmission of height; and that family background can be another important explanatory variable (Maher 2008). Thus, when it is impossible to directly measure childhood health, researchers often use adult height as proxy to measure childhood health and life conditions (Power et al. 1986; Fogel 1994; Deaton 2008; Case and Paxson 2008). This article also uses this method.

So far, we have discussed the important mediating role that childhood health plays in social reproduction. Therefore, this study will first examine the impact of parental SES on childhood health. Based on the existing data, we use nutrient intake and hygiene to describe the family background that influences childhood health. Then, we will analyze the impacts of childhood health (using height as proxy) on individual educational attainment and SES. More specifically, the following hypothesis will be tested:

Hypothesis 1a Higher family SES (measured by father's ISEI by age 14, parental educational attainment, parental household registration status) is associated with better childhood nutritional and hygienic condition.

Hypothesis 1b Better childhood nutritional and hygienic conditions are associated with better childhood health (measured by height).

\footnotetext{
${ }^{3}$ In China, currently there is no large longitudinal dataset that can be applied to analyze childhood health-for example, the CFPS dataset is still very recent. Other datasets may not be very useful due to their small sample size. In the study of He and Yuan (2014), for example, the CHNS data that they used include only 494 samples.
} 
Hypothesis 2a Better childhood health (measured by height) is associated with more years of schooling one receives.

Hypothesis 2b Better childhood health (measured by height) is associated with higher adult SES (measured by the ISEI of first job and of current job).

Hypothesis 2c Better childhood health (measured by height) is associated with better current health state.

\section{Data, variables and models}

This research uses the data from the "Urbanization and Labor Migration Survey" (hereafter referred as Tsinghua survey) conducted by Tsinghua University in 2012. The survey collected the information from 12,592 participants aged 18-69. The samples covered 500 villages/ residential communities from 147 districts/ counties in 28 provinces, autonomous regions, and direct-administered municipalities (that is, all the country's provincial-level administrative divisions except Qinghai, Tibet, and Hainan). The sampling in villages/ residential communities was based on mapping in the field, which created a sample space consisting of a list of addresses.

Two types of dependent variables are included: (1) individual's current SES, using the ISEI score of respondent's current job as proxy ${ }^{4}$; and (2) individual's self-assessment of current state of health ( $4=$ excellent, $3=$ good, $2=$ fair, and $1=$ poor).

Five independent variables are used in this study. First, childhood nutrition and hygiene condition by or before age 14 include 4 measures. Two measures are used to describe hygienic condition: (1) main sources of potable water at age of 14 ( $3=$ centralized water system or bottled water; $2=$ well or spring water; $1=$ water from sources such as a reservoir, river, creek, pond, lake, or rainwater), and (2) type of sanitation amenity at age of 14 ( $3=$ flush toilet; $2=$ non-flush toilet; $3=$ other places, such as yard, livestock pen, pond, sea, lake, creek, river, or gutter). ${ }^{5}$ The other two measures describe nutrient intake: (1) whether suffering hanger due to insufficient food supply before age of 14 $(1=$ never; $2=$ sometimes; $3=$ often), and (2) frequency of eating fish or diary product before age of 14 (ranging from $0=$ never to $8=$ at least once per day). Second, childhood health is measured by adult height (in centimeter, interval variable). Third, family SES includes the ISEI score for father's job when respondent was at the age of $14,{ }^{6}$ parental educational attainment $(0=$ never attend school; $1=$ primary school; $2=$ middle school; $3=$ high school or above), parental household registration status ( $1=$ urban; $0=$ rural).

\footnotetext{
${ }^{4}$ If the ISEI score of current job is not available, we used the ISEI scores of the last job instead. This, according to our results, makes no significant difference from simply deleting those cases from the sample. In addition, we did not use individual income when measuring SES. This is because this information is usually only available among formal employees and self-employed. However, $25 \%$ of the survey respondents were migrant workers of rural origin and $13 \%$ were dedicated to domestic work. Their income is often unclear or is only roughly added to their family income. To avoid having to delete a large number of samples or dealing with the unclear data, we followed the reviewers' advice and used ISEI score of current job to measure respondent's current SES.

${ }^{5}$ As required by the structural equation modeling method, we treated the two hygiene measures as ordinal variables. In Table 2, the gradient relationship between these two variables and adult SES somehow supports this practice.

${ }^{6}$ We only included the ISEI score for father's job in the model because many mothers did not hold formal employment, causing a large amount of missing data.
} 
Table 1 Description of variables

\begin{tabular}{|c|c|c|}
\hline \multicolumn{3}{|l|}{$N=6726$} \\
\hline Variables & $\begin{array}{l}\text { Mean/ } \\
\text { percentage }\end{array}$ & Notes \\
\hline $\begin{array}{l}\text { Father's ISEl score when respondent was at } \\
\text { age } 14\end{array}$ & $23.31(15.82)$ & Range: $11.74-85.41$ \\
\hline \multicolumn{3}{|l|}{ Father's educational attainment } \\
\hline Never attended school & $43.03 \%$ & \\
\hline Primary school & $38.27 \%$ & \\
\hline Middle school & $11.30 \%$ & \\
\hline High school or above & $7.39 \%$ & \\
\hline \multicolumn{3}{|l|}{ Mother's educational attainment } \\
\hline Never attended school & $62.96 \%$ & \\
\hline Primary school & $27.52 \%$ & \\
\hline Middle school & $6.13 \%$ & \\
\hline High school or above & $3.39 \%$ & \\
\hline $\begin{array}{l}\text { Father's household registration status when } \\
\text { respondent was at age } 14\end{array}$ & $0.163(0.369)$ & $\begin{array}{l}\text { Non-agricultural household registration }=1 \text {; } \\
\text { agricultural household registration }=0\end{array}$ \\
\hline $\begin{array}{l}\text { Mother's household registration status when } \\
\text { respondent was at age } 14\end{array}$ & $0.132(0.338)$ & $\begin{array}{l}\text { Non-agricultural household registration }=1 \text {; } \\
\text { agricultural household registration }=0\end{array}$ \\
\hline Sex & $0.506(0.5)$ & Male $=1 ;$ female $=0$ \\
\hline Age & $43.97(8.67)$ & Range: 30-60 \\
\hline Ethnicity & $0.913(0.282)$ & Ethnic $\operatorname{Han}=1$; ethnic minority $=0$ \\
\hline Frequency of eating fish etc & $3.398(2.156)$ & $\begin{array}{l}\text { Range: } 0-8 \text {, from "never eat" to "at least once } \\
\text { per day" }\end{array}$ \\
\hline Height (cm) & $163.44(7.89)$ & Range: 110-197 \\
\hline Years of schooling & $7.890(4.249)$ & Range: 0-19 \\
\hline ISEl of first job & $26.37(16.47)$ & Range: 11.74-88.7 \\
\hline ISEI of current job & $29.31(17.81)$ & Range: $11.74-88.96$ \\
\hline \multicolumn{3}{|l|}{ Self-assessment of current state of health } \\
\hline Poor & $7.55 \%$ & \\
\hline Fair & $29.42 \%$ & \\
\hline Good & $39.30 \%$ & \\
\hline Excellent & $23.73 \%$ & \\
\hline
\end{tabular}

(1) standard deviations in parentheses; (2) the variables "experience of suffering hunger", "source of drinking water" and "type of sanitation amenity" are listed in the column 5 of Table 2 (in percentage)

Fourth, respondent's educational attainment is measured by years of schooling. The fifth one is ISEI score for respondent's first job.

All the five independent variables are endogenous except family SES. The exogenous control variables include respondent's age, sex $(1=$ male; $0=$ female $)$, and ethnicity ( $1=$ ethnic Han; $0=$ ethnic minorities). A description of the variables can be found in Tables 1 and 2. The correlation coefficients among variables can be found in "Appendix Table 1".

The sample size of Tsinghua survey is 12,592. Considering the timing of entering into and withdrawing from the labor market, our study targets respondents aged 30-60, which reduces the sample size to 8256 . We also deleted $18.53 \%$ of the cases due to missing data, which further reduced our sample size to 6726 , based on which we ran 
Table 2 Correlations between the variables of childhood nutrient intake and hygiene, height, and adult SES

\begin{tabular}{lllll}
\hline Variables & Years of schooling & ISEI of first job & ISEl of current job & Sample size (\%) \\
\hline Experience of suffering hunger & & & & \\
Never & $9.48^{* * *}$ & $30.61^{* * *}$ & $34.32^{* * *}$ & $2802(41.66 \%)$ \\
Occasionally & 7.56 & 24.76 & 28.25 & $2127(31.62 \%)$ \\
Often & 5.80 & 21.68 & 22.75 & $1797(26.72 \%)$ \\
Source of drinking water & & & & \\
Running water /bottled water & $11.38^{* * *}$ & $36.18^{* * *}$ & $40.67^{* * *}$ & $1123(16.70 \%)$ \\
Well water/spring water & 7.28 & 24.31 & 27.14 & $4883(72.60 \%)$ \\
Reservoir or other & 6.60 & 25.06 & 26.33 & $720(10.70 \%)$ \\
Type of sanitary amenity & & & & $700(10.41 \%)$ \\
Flush toilet & $11.52^{* * *}$ & $38.45^{* * *}$ & $42.80^{* * *}$ & $4771(70.93 \%)$ \\
Non-flush toilet & 7.74 & 25.67 & 28.72 & $1255(18.66 \%)$ \\
Others & 6.42 & 22.30 & 24.03 & 6726 \\
Frequency of eating fish and & $0.342^{* * *}$ & $0.245^{* * *}$ & $0.286^{* * *}$ & 6726 \\
meat $(r)$ & & & & $0.184^{* * *}$ \\
Height $(r)$ & $0.300^{* * *}$ & $0.162^{* * *}$ & & \\
\hline
\end{tabular}

We measure the correlation of "frequency of eating fish and meat", "height" with adult SES variables with Pearson's $r$. Other numbers in the table are the mean of their respective categories, and the significance of the $F$ test is also reported ${ }^{*} p<0.05$; ${ }^{* *} p<0.01$; ${ }^{* * *} p<0.001$

analysis. $^{7}$ This research is also an expansion of the traditional models of status acquisition: we treat childhood health as both the outcome and the cause of social stratification. Whereas conventional regression analysis is unable to examine the causal and structural relationship between multiple variables, we use structural equation model to analyze the structural relationships among variables of childhood health, education, and SES acquisition, based on Pakpahan et al. (2017) and Warren (2009)'s research. The statistical analysis is run using Amos24.0.

\section{Results}

Table 2 examines the correlations among variables of childhood nutrition and hygiene, height (a proxy for childhood health), and adult SES (including years of schooling, ISEI of first job, and ISEI of current job). For the nominal variables of nutrient intake and hygiene, we reported the mean value of adult SES variables in different nutritional/ hygienic categories. For the interval variables, we reported the Pearson's correlation coefficients $(r)$. According to results shown in Table 2, those who never suffered hunger before age 14 have significant advantage in education, ISEI of first job and ISEI of current job, compared to those who occasionally or often suffered hunger before age 14. For example, those who never suffered hunger on average attended school for 3.7 more years compared to those who did. As for sources of potable water, respondents who drank water from a centralized water system or bottled water have much higher SES than those who relied on other sources for potable water. The variable "type of sanitation amenity" has similar effects on SES variables. In addition, the variables "frequency of eating fish

\footnotetext{
${ }^{7}$ We also ran multiple imputation (MI), but the model results were not very different from the casewise deletion results. Therefore, this article only reports the results of the analysis on the sample with all the missing data removed.
} 


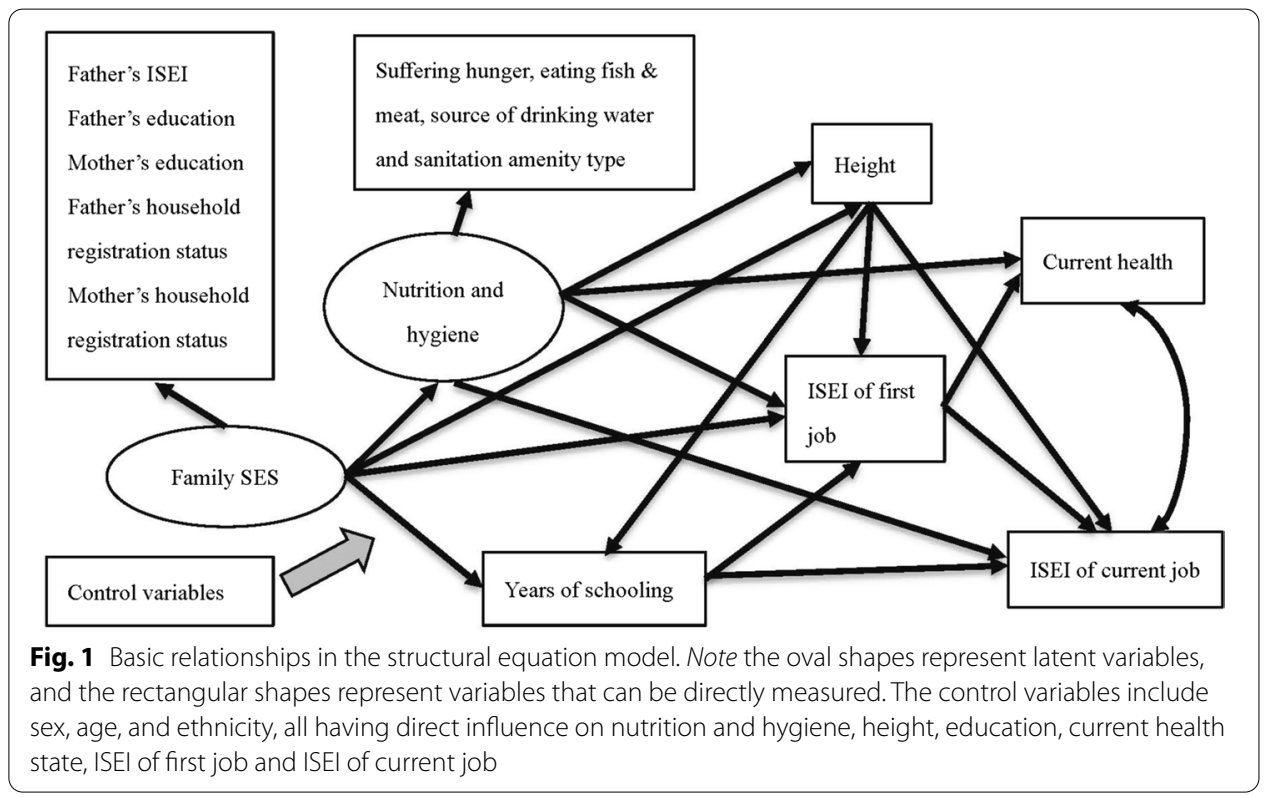

etc., "adult height", and of adult SES also have significant, positive correlation. That being said, it is possible that childhood nutrition, hygiene, and health reflect the impacts of other social and economic resources of the family. Therefore, it is necessary to introduce control variables to examine the effects of childhood nutrition, hygiene, and health.

To clarify the mechanisms and pathways of the effects of childhood nutrition, hygiene, and health, we conducted an SEM analysis. As shown in Fig. 1 and Table 3, we use "father's ISEI when respondent was at age of 14", "parental educational attainment", "parental household registration status" to measure respondent's family SES; use "experience of suffering hunger", "frequency of eating fish etc., "sources of drinking water", and "type of sanitation amenity" to measure childhood nutrition, and hygiene; and use "ISEI of current job" to measure respondents' current SES. We develop a structural model that includes these three latent variables, respondent's years of schooling, ISEI of respondent's first job, and self-assessment of current health state. Meanwhile, we control the effects of "sex", "ethnicity", and "age" on childhood nutrition and hygiene, ISEI of first job, education, ISEI of current job, and current health state. The correlations among the variables are shown in Fig. 1. We assume that family's SES and ISEI of current job have no direct effect on health- that effect is mediated through childhood health, education, and ISEI of first job. As it is difficult to assert the causal relationship between ISEI of current job and health-mutual causality may exist here-we set their relationship as correlated. $^{8}$

The goodness of fit of the structural equation model concludes that the causal model of Fig. 1 can be accepted. The CMIN/df is high. Yet, the chi square is closely associated with the sample size. Due to the large sample size used in this research, the RMSEA is a

\footnotetext{
${ }^{8}$ For the identifiability of the model, we suppose that childhood health does not affect educational attainment. Even if we apply other constrained models, the estimated results show that the pathway from childhood health to educational attainment is not significant. Table 2 shows that childhood nutrition and hygiene may be significantly correlated with educational attainment. This correlation, however, may be a false one according to the SEM results. The correlation disappears when variables of family SES and height are added.
} 
Table 3 Results from the structural equation modeling analysis

\begin{tabular}{|c|c|c|c|c|c|c|}
\hline \multicolumn{4}{|l|}{$N=6726$} & \multirow[b]{2}{*}{$\begin{array}{l}\text { Unstandardized } \\
\text { coefficient }\end{array}$} & \multirow[b]{2}{*}{ SE } & \multirow[b]{2}{*}{$\begin{array}{l}\text { Standardized } \\
\text { coefficient }\end{array}$} \\
\hline & & & & & & \\
\hline \multicolumn{7}{|l|}{ Measurement model } \\
\hline $\begin{array}{l}\text { Father's ISI when respondent } \\
\text { was at age } 14\end{array}$ & $\leftarrow$ & \multicolumn{2}{|l|}{ Family SES } & 1.000 & - & 0.510 \\
\hline $\begin{array}{l}\text { Mother's educational attain- } \\
\text { ment }\end{array}$ & $\leftarrow$ & \multicolumn{2}{|l|}{ Family SES } & $0.054^{* * *}$ & 0.002 & 0.579 \\
\hline $\begin{array}{l}\text { Father's educational attain- } \\
\text { ment }\end{array}$ & $\leftarrow$ & \multicolumn{2}{|l|}{ Family SES } & $0.062^{* * *}$ & 0.002 & 0.558 \\
\hline $\begin{array}{l}\text { Father's household registration } \\
\text { status when respondent was } \\
\text { at age } 14\end{array}$ & $\leftarrow$ & \multicolumn{2}{|l|}{ Family SES } & $0.028^{* * *}$ & 0.001 & 0.615 \\
\hline $\begin{array}{l}\text { Mother's household registra- } \\
\text { tion status when respondent } \\
\text { was at age } 14\end{array}$ & $\leftarrow$ & \multicolumn{2}{|l|}{ Family SES } & $0.026^{* * *}$ & 0.001 & 0.615 \\
\hline Whether suffered hunger & $\leftarrow$ & \multicolumn{2}{|c|}{$\begin{array}{l}\text { Childhood nutrition and } \\
\text { hygiene }\end{array}$} & 1.000 & - & 0.447 \\
\hline Source of drinking water & $\leftarrow$ & \multicolumn{2}{|c|}{$\begin{array}{l}\text { Childhood nutrition and } \\
\text { hygiene }\end{array}$} & $0.836^{* * *}$ & 0.035 & 0.577 \\
\hline Type of sanitation amenity & $\leftarrow$ & \multicolumn{2}{|c|}{$\begin{array}{l}\text { Childhood nutrition and } \\
\text { hygiene }\end{array}$} & $0.738^{* * *}$ & 0.034 & 0.497 \\
\hline Nutrient intake & $\leftarrow$ & \multicolumn{2}{|c|}{$\begin{array}{l}\text { Childhood nutrition and } \\
\text { hygiene }\end{array}$} & $2.900^{* * *}$ & 0.115 & 0.487 \\
\hline \multicolumn{7}{|l|}{ Structural model } \\
\hline $\begin{array}{l}\text { Childhood nutrition and } \\
\text { hygiene }\end{array}$ & $\leftarrow$ & \multicolumn{2}{|l|}{ Family SES } & $0.034^{* * *}$ & 0.002 & 0.775 \\
\hline Height & $\leftarrow$ & \multicolumn{2}{|c|}{$\begin{array}{l}\text { Childhood nutrition and } \\
\text { hygiene }\end{array}$} & $2.098^{* *}$ & 0.757 & 0.095 \\
\hline Height & $\leftarrow$ & \multicolumn{2}{|l|}{ Family SES } & $0.106^{* * *}$ & 0.031 & 0.108 \\
\hline Years of schooling & $\leftarrow$ & \multicolumn{2}{|l|}{ Family SES } & $0.334^{* * *}$ & 0.012 & 0.645 \\
\hline Years of schooling & $\leftarrow$ & \multicolumn{2}{|l|}{ Height } & $0.020^{*}$ & 0.008 & 0.038 \\
\hline ISEl of first job & $\leftarrow$ & \multicolumn{2}{|l|}{ Family SES } & $0.518^{* * *}$ & 0.081 & 0.255 \\
\hline ISEl of first job & $\leftarrow$ & \multicolumn{2}{|l|}{ Height } & -0.003 & 0.031 & -0.001 \\
\hline ISEl of first job & $\leftarrow$ & \multicolumn{2}{|c|}{$\begin{array}{l}\text { Childhood nutrition and } \\
\text { hygiene }\end{array}$} & 0.093 & 1.418 & 0.002 \\
\hline ISEl of first job & $\leftarrow$ & \multicolumn{2}{|l|}{ Years of schooling } & $1.275^{* * *}$ & 0.079 & 0.326 \\
\hline ISEl of current job & $\leftarrow$ & \multicolumn{2}{|l|}{ Height } & 0.023 & 0.028 & 0.011 \\
\hline ISEl of current job & $\leftarrow$ & \multicolumn{2}{|c|}{$\begin{array}{l}\text { Childhood nutrition and } \\
\text { hygiene }\end{array}$} & $6.647^{* * *}$ & 1.110 & 0.134 \\
\hline ISEl of current job & $\leftarrow$ & \multicolumn{2}{|l|}{ Years of schooling } & $0.696^{* * *}$ & 0.061 & 0.165 \\
\hline ISEl of current job & $\leftarrow$ & \multicolumn{2}{|l|}{ ISEI of first job } & $0.563^{* * *}$ & 0.011 & 0.522 \\
\hline $\begin{array}{l}\text { Self-assessment of current } \\
\text { state of health }\end{array}$ & $\leftarrow$ & \multicolumn{2}{|l|}{ Height } & $0.017^{* * *}$ & 0.002 & 0.150 \\
\hline $\begin{array}{l}\text { Self-assessment of current } \\
\text { state of health }\end{array}$ & $\leftarrow$ & $\begin{array}{l}\text { Childhood nutriti } \\
\text { hygiene }\end{array}$ & on and & $0.179 * * *$ & 0.053 & 0.072 \\
\hline $\begin{array}{l}\text { Self-assessment of current } \\
\text { state of health }\end{array}$ & $\leftarrow$ & Years of schooling & & $0.009^{*}$ & 0.004 & 0.042 \\
\hline $\begin{array}{l}\text { Self-assessment of current } \\
\text { state of health }\end{array}$ & & ISEl of first job & & 0.000 & 0.001 & -0.003 \\
\hline $\mathrm{CMIN}=1463.44 ; d f=67 ; \mathrm{CMIN}$ & $1 / d f=$ & 21.8 & RMSE & $056 ; \mathrm{NFI}=0.965 ; \mathrm{Tl}$ & $I=0.9$ & $33 ; \mathrm{CFI}=0.967$ \\
\hline Pathway & & & Effect & & & \\
\hline $\begin{array}{l}\text { Family SES } \rightarrow \text { Nutrition and } h \\
\text { job }\end{array}$ & & rent & 0 & 0.14 & & \\
\hline
\end{tabular}


Table 3 (continued)

\begin{tabular}{|c|c|}
\hline $\begin{array}{l}\mathrm{CMIN}=1463.44 ; d f=67 ; \mathrm{CMIN} / d f=21.8 \\
\text { Pathway }\end{array}$ & $\begin{array}{l}\text { RMSEA }=0.056 ; \mathrm{NFI}=0.965 ; \mathrm{TLI}=0.933 ; \mathrm{CFI}=0.967 \\
\text { Effect }\end{array}$ \\
\hline $\begin{array}{l}\text { Family SES } \rightarrow \text { Nutrition and hygiene } \rightarrow \text { height } \rightarrow \text { edu- } \\
\text { cation } \rightarrow \text { ISEl of current job }\end{array}$ & $0.775 \times 0.095 \times 0.038 \times 0.165=0.0005$ \\
\hline $\begin{array}{l}\text { Family SES } \rightarrow \text { Nutrition and hygiene } \rightarrow \text { height } \rightarrow \text { edu- } \\
\text { cation } \rightarrow \text { ISEl of first job } \rightarrow \text { ISEl of current job }\end{array}$ & $0.775 \times 0.095 \times 0.038 \times 0.326 \times 0.522=0.0005$ \\
\hline Family SES $\rightarrow$ Height $\rightarrow$ Education $\rightarrow$ ISEl of current job & $0.108 \times 0.038 \times 0.165=0.0006$ \\
\hline $\begin{array}{l}\text { Family SES } \rightarrow \text { Height } \rightarrow \text { Education } \rightarrow \text { ISEl of first } \\
\text { job } \rightarrow \text { ISEI of current job }\end{array}$ & $0.108 \times 0.038 \times 0.326 \times 0.522=0.0007$ \\
\hline Family SES $\rightarrow$ ISEl of first job $\rightarrow$ ISEl of current job & $0.255 \times 0.522=0.133$ \\
\hline Family SES $\rightarrow$ Education $\rightarrow$ ISEl of current job & $0.645 \times 0.165=0.106$ \\
\hline $\begin{array}{l}\text { Family SES } \rightarrow \text { Education } \rightarrow \text { ISEl of first job } \rightarrow \text { ISEl of } \\
\text { current job }\end{array}$ & $0.645 \times 0.326 \times 0.522=0.110$ \\
\hline
\end{tabular}

satisfactory goodness of fit. As shown in Table 3, the RMSEA is smaller than 0.08, suggesting a fair goodness of fit. The values of NFI, TLI and CFI are all above 0.9 (Wu 2010: 486-491), suggesting a high goodness of fit.

As shown in Table 3, the measurement model results (part 1) suggest that all the indicators we selected are significantly related to the latent variables that we want to measure. The structural model results (part 2) show that childhood nutrition and hygiene, as well as childhood health consist in an important pathway of social reproduction. First, family SES has significant impact on respondent's childhood nutrition and hygiene, and respondent's height. In the influence of family SES on height, approximately $40.5 \%$ of the influence is from the effects of childhood nutrition and hygiene. Thus, Hypotheses $1 \mathrm{a}$ and $1 \mathrm{~b}$ are both supported. Second, we found significant positive impacts of height on years of schooling. Each $10 \mathrm{~cm}$ of increase in respondent's height is correlated to 0.2year increase in year of schooling, which supports the Hypothesis 2a. Third, respondent's height and childhood nutrition and hygiene do not have significant effects on first job's ISEI; meanwhile, the acquisition of the first job is impacted by family SES and educational attainment. The effects of height are completely mediated by education. Fourth, childhood nutrition and hygiene have highly significant effect on the ISEI of current job. Height does not have significant impact. The standardized coefficients suggest that childhood nutrition and hygiene have similar effects on ISEI of current job as education, which is $1 / 4$ of the effects of the ISEI of the first job. Hypothesis $2 b$ is not supported, since childhood health, measured by respondent's height, has no significant impacts on the ISEI of the first job and the current job. Fifth, self-assessment of the current health state is highly influenced by childhood nutrition and hygiene, as well as height; the effects of these two variables are 5 times as large as the effects of education. ISEI of the first job does not have significant impacts. Thus, Hypothesis $2 \mathrm{c}$ is supported.

Part 3 of Table 3 reveals the pathways of the effects of family's SES on respondent's ISEI of the current job. The effects of "childhood nutrition and hygiene" and "height" combine to count for as much as $23.3 \%$ of the total impacts of family SES on ISEI of current job, with the pathway "childhood nutrition and hygiene - ISEI of current job" 
counting for $22.9 \%$. The direct effects of education and of ISEI of first job are similar, counting for $23.3 \%$ and $29.2 \%$ of the impacts, respectively. The mixed indirect effects of adding education and ISEI of first job count for $24.2 \%$. This means that $3 / 4$ of the intergenerational transmission of SES occurs through the conventional pathways of education and first job (as in the Blau-Duncan Model), and the rest $1 / 4$ is explained by childhood nutrition, hygiene, and health.

"Childhood nutrition and hygiene" and "height" have no significant impact on the acquisition of first job, but "childhood nutrition and hygiene" has significant impact on the ISEI score of respondent's current job. This is consistent with previous studies on the topic (Case et al. 2002); that is, as lives unfold, the impacts of childhood health on adult SES are also amplified. Our explanation of this delay is that individuals tend to be healthy in the early adulthood, but as they age, their health conditions are also stratified. In the Tsinghua survey sample, only $0.94 \%$ of the respondents aged 25-30 reported poor health, while $80.5 \%$ reported good or very good health. Among respondents aged $31-40,3.59 \%$ viewed their health state as poor and $73.2 \%$ as good or very good. The proportion of the respondents reporting poor health state increased to $10.7 \%$, and those reporting good or very good health dropped to $55.9 \%$. This somehow confirms what Marmot (2004) called "incubation mode." The impact of childhood health is often only latent when young individuals just enter job market, but it becomes increasingly manifest as they age. Numerous studies in the West also reached similar conclusions (e.g., Hass 2008; Currie et al. 2010; Pakpahan et al. 2017).

Our analysis of the factors that influence self-assessment of current health state also supports the health-selection argument. The status of first job does not have significant impact on one's self-assessment of current health condition. The effect of "education" is reduced compared to "childhood nutrition and hygiene" and "height". This, of course, does not mean a complete rejection to the social causality argument. Education still has significant positive impact on one's self-assessment of current health state. This somehow supports the Ross and Mirowsky (2010)'s viewpoint, that is, among the three variables of "occupation", "income", and "education," education is the key factor of health. Therefore, based on the results from the structural equation modeling analysis, we argue that family background has significant impacts on individual's childhood nutrition, hygiene, and health. Childhood health can influence educational attainment, but its impact on first job acquisition is minimal. The effect of childhood health is cumulative: it remains latent during early adulthood, but it gets more prominent in later life stages when individual health conditions are increasingly stratified.

\section{Conclusions and discussion}

Existing research in China on social stratification and mobility has been largely focusing on education, and research on health inequality tends to focus on the influence of adult socioeconomic status on health, or what Marmot (2004) called "status symptom." This research examines the role of health in the process of intergenerational social reproduction. We conclude that childhood nutrition, hygiene and health can have lasting impacts on adult SES, and stratification in childhood health is an important mechanism that creates and reproduces social stratification and social inequality. 
The structural equation modeling analysis of the data from the Tsinghua University "Urbanization and Labor Migration Survey" reveals that, health and education are two important pathways for intergenerational social reproduction. However, their influences vary with stages of life course. First, family background has significant positive influence on childhood nutrition, hygiene, and health (using height as proxy). Second, childhood health has significant influence on education. Third, "childhood nutrition and hygiene" and "childhood health" have no significant influence on the acquisition of first job; but "childhood nutrition and hygiene" has significant impact on the ISEI of current job, with an effect similar to the direct effect of education. When young people first enter labor market, they tend to be in good health condition and their job acquisition is mainly influenced by their family SES and individual educational attainment. As they age, their health conditions are also increasingly stratified, and the effects of childhood health on occupational status and income also become manifest and significant. The effects of health and education are cumulative but in different ways. For members of a society, their educational attainments are likely to remain stable after certain age, but the cumulative effects of health are persistent until individuals permanently leave labor market or die. Childhood health has significant influence on current health state, which explains why the effects of childhood health are persistent and stable. Fourth, although it is questionable whether adult height is an accurate proxy to measure childhood health, we view it as a useful alternative when direct and objective measures are not available.

Incorporating health inequality in the analysis of social stratification can help to resolve the disagreement between the health selection theory and the social causation theory in the existing literature. According to Wang (2011), the social causation theory has greater explanatory power in China, although the health selection theory fits better when explaining the social gradient in health between manual and non-manual labor. In other words, different theories may fit better when applied on different social groups. In our opinion, the reason why these two theories show contradicting empirical evidence is that the relationship between health and SES varies with stages of life course. In the early stages of life course, family SES is a key determinant of childhood health, suggesting a greater explanatory power of the social causation theory. As adults enter job market, the health selection theory becomes increasingly relevant. Therefore, both theories are valid for explaining the dynamics of social stratification. In social stratification and social mobility research, health should not be viewed merely as a result of social stratification. Rather, we need to explore the role of health in the dynamics of social stratification. This will expand the horizon of the stratification research and deepen our understanding on social stratification and social mobility in China and other countries.

The results of the structural equation model reveals that the effect of childhood nutrition, hygiene and health on social reproduction is about half of the effect of education. Thus, childhood health and their key factors should not be overlooked in social stratification and social mobility research. Exclusively focusing on the role of education in social stratification and overlooking the role of health may lead to victim blaming. Children from low-income families are more likely to suffer poor health, which hinders their 
physical and cognitive development; even they are given the same education opportunity as their affluent peers, they tend to fall behind in school. Society tends to attribute their poor performance to individual idiosyncrasies, such as IQ, efforts, etc., which is counterproductive for reducing class rigidity and social inequality. Although poor childhood health hinders individuals' future development, it does not mean that the damage cannot be repaired. Many policy initiatives can potentially mitigate the negative impacts of poor childhood health (Almond and Currie 2011). Research has found that the intergenerational transmission of health conditions varies from place to place. In Indonesia, the intergenerational correlation of health in economically developed regions is relatively weak, comparing to that in undeveloped regions (Almond et al. 2012; Kim et al. 2015). The highly developed social security system in Australia has virtually eliminated the impact of mother's mental disorder on children (Le and Nguyen 2015). In China, where the popular saying "Don't let your children lose at the starting line" is widely accepted, how to effectively reduce inequality in childhood health is closely related to future human capital and labor productivity, and to mitigate "class crystallization"- a heated debate topic in the country. First, "dietary supplements programs" (such as midday meal program) will be necessary for low-income pregnant women and children. Improving the nutrient intake among low-income children will help to reduce future educational and social inequality. Research in other countries has shown that dietary supplements programs can significantly improve infants' nutritional conditions and benefit their future development (Habicht et al. 1995; Campbell et al. 2014). Second, improving the hygienic conditions and personal hygiene habits among vulnerable and low-income population is also a critical intervention measure. Third, simply improving medical service for impoverished children does not suffice. To improve their health conditions requires not only treating their diseases, but also improving the overall conditions of their family (Santrock 2009: 132).

This article has several limitations. First, collecting data on childhood health is a serious challenge, which requires not only high-quality data collection, but also a thorough discussion on the weight of the influence of genetic factors and of family resources on health outcomes. Second, in the cross-sectional data used in this research, it is often impossible to capture the premature deaths from health problems among earlier cohorts. However, this only leads to an underestimation of the impacts of health on education and SES acquisition (Haas 2006) and will not alter the conclusions of this study. Third, we have not found an effective solution to the endogeneity issue. SES variables such as parental educational attainments contain genetic factors of capabilities, but they are not good proxy variables because genetic factors can influence the SES acquisition of both parents and children. The fourth challenge is associated with controlling for family background variables. Although the variables of nutrition, hygiene and health may reflect the family income levels after controlling for the family background variables, data on respondent's family income during childhood remain largely unavailable in the cross-sectional data. We hope to obtain larger high-quality datasets in the future in order to further examine the complex mechanisms through which childhood health impacts individuals' future SES acquisition. 


\section{Appendix Table 1: Correlation coefficients between variables}

\begin{tabular}{|c|c|c|c|c|c|c|c|c|c|}
\hline \multicolumn{10}{|l|}{$N=6726$} \\
\hline & 1 & 2 & 3 & 4 & 5 & 6 & 7 & \multicolumn{2}{|c|}{8} \\
\hline 1. Height & 1 & & & & & & & & \\
\hline $\begin{array}{l}\text { 2. Experi- } \\
\text { ence of } \\
\text { suffering } \\
\text { hunger }\end{array}$ & $0.110^{* * *}$ & 1 & & & & & & & \\
\hline $\begin{array}{l}\text { 3. Fre- } \\
\text { quency of } \\
\text { eating fish } \\
\text { and meat }\end{array}$ & $0.107^{* * *}$ & $0.443^{* * *}$ & 1 & & & & & & \\
\hline $\begin{array}{l}\text { 4. Source } \\
\text { of drink- } \\
\text { ing water }\end{array}$ & $0.120^{* * *}$ & $0.282^{* * *}$ & $0.307^{* * *}$ & 1 & & & & & \\
\hline $\begin{array}{l}\text { 5. Type of } \\
\text { sanitation } \\
\text { amenity }\end{array}$ & $0.136^{* * *}$ & $0.239^{* * *}$ & $0.308^{* * *}$ & $0.338^{* * *}$ & 1 & & & & \\
\hline $\begin{array}{l}\text { 6. Father's } \\
\text { ISEI }\end{array}$ & $0.070^{* * *}$ & $0.175^{* * *}$ & $0.187^{* * *}$ & $0.239^{* * *}$ & $0.204^{* * *}$ & 1 & & & \\
\hline $\begin{array}{l}\text { 7. Father's } \\
\text { education }\end{array}$ & $0.102^{* * *}$ & $0.286^{* * *}$ & $0.278^{* * *}$ & $0.264^{* * *}$ & $0.241^{* * *}$ & $0.471^{* * *}$ & 1 & & \\
\hline $\begin{array}{l}8 . \\
\text { Mother's } \\
\text { education }\end{array}$ & $0.115^{* * *}$ & $0.299^{* * *}$ & $0.305^{* * *}$ & $0.323^{* * *}$ & $0.251^{* * *}$ & $0.332^{* * *}$ & $0.644^{* * *}$ & 1 & \\
\hline $\begin{array}{l}\text { 9. Years of } \\
\text { schooling }\end{array}$ & $0.300^{* * *}$ & $0.353^{* * *}$ & $0.342^{* * *}$ & $0.326^{* * *}$ & $0.288^{* * *}$ & $0.321^{* * *}$ & $0.441^{* * *}$ & $0.436^{* * *}$ & \\
\hline $\begin{array}{l}\text { 10. ISEl of } \\
\text { first job }\end{array}$ & $0.162^{* * *}$ & $0.225^{* * *}$ & $0.245^{* * *}$ & $0.208^{* * *}$ & $0.230^{* * *}$ & $0.285^{* * *}$ & $0.292^{* * *}$ & $0.284^{* * *}$ & \\
\hline $\begin{array}{l}\text { 11. ISEl of } \\
\text { current } \\
\text { job }\end{array}$ & $0.184^{* * *}$ & $0.265^{* * *}$ & $0.286^{* * *}$ & $0.239 * * *$ & $0.252^{* * *}$ & $0.271^{* * *}$ & $0.302^{* * *}$ & $0.311^{* * *}$ & \\
\hline $\begin{array}{l}\text { 12. Self- } \\
\text { assess- } \\
\text { ment of } \\
\text { health } \\
\text { condi- } \\
\text { tions }\end{array}$ & $0.205^{* * *}$ & $0.197^{* * *}$ & $0.142^{* * *}$ & $0.090^{* * *}$ & $0.087^{* * *}$ & 0.002 & $0.084^{* * *}$ & $0.113^{* * *}$ & \\
\hline 13. Age & $\overline{0.076^{* * *}}$ & $\overline{0.434 * * *}^{*}$ & $\overline{0.336^{* * *}}$ & $\overline{0.157^{* * *}}$ & $\overline{0.153^{* * *}}$ & $-0.022^{\#}$ & $\overline{0.307^{* * *}}$ & $\overline{0.314^{* * *}}$ & \\
\hline $\begin{array}{l}14 . \\
\text { Father's } \\
\text { house- } \\
\text { hold reg- } \\
\text { istration } \\
\text { status }\end{array}$ & $0.117^{* * *}$ & $0.221^{* * *}$ & $0.243^{* * *}$ & $0.416^{* * *}$ & $0.305^{* * *}$ & $0.526^{* * *}$ & $0.385^{* * *}$ & $0.392^{* * *}$ & \\
\hline $\begin{array}{l}15 . \\
\text { Mother's } \\
\text { house- } \\
\text { hold reg- } \\
\text { istration } \\
\text { status }\end{array}$ & $0.126^{* * *}$ & $0.217^{* * *}$ & $0.262^{* * *}$ & $0.463^{* * *}$ & $0.331^{* * *}$ & $0.436^{* * *}$ & $0.341^{* * *}$ & 0.405 & \\
\hline 16. Male & $0.658^{* * *}$ & $-\overline{0.055^{* * *}}$ & 0.012 & -0.009 & $0.021^{\#}$ & -0.015 & $-0.023^{\#}$ & $-0.024^{\#}$ & \\
\hline \multirow{2}{*}{$\begin{array}{l}\text { 17. Han } \\
\text { ethnicity }\end{array}$} & $0.078^{* * *}$ & $0.032^{* *}$ & $0.045^{* * *}$ & 0.016 & $0.092^{* * *}$ & $0.039^{* *}$ & $0.031^{*}$ & $0.029^{*}$ & \\
\hline & 9 & 10 & I & & & 13 & 15 & 16 & 17 \\
\hline
\end{tabular}




\begin{tabular}{|c|c|c|c|c|c|c|c|c|c|}
\hline & 9 & 10 & 11 & 12 & 13 & 14 & 15 & 16 & 17 \\
\hline \multicolumn{10}{|l|}{$\begin{array}{l}\text { 2. Experience of } \\
\text { suffering hunger }\end{array}$} \\
\hline \multicolumn{10}{|l|}{$\begin{array}{l}\text { 3. Frequency of } \\
\text { eating fish and } \\
\text { meat }\end{array}$} \\
\hline \multicolumn{10}{|l|}{$\begin{array}{l}\text { 4. Source of } \\
\text { drinking water }\end{array}$} \\
\hline \multicolumn{10}{|l|}{$\begin{array}{l}\text { 5. Type of sanita- } \\
\text { tion amenity }\end{array}$} \\
\hline \multicolumn{10}{|l|}{ 6. Father's ISEI } \\
\hline \multicolumn{10}{|l|}{$\begin{array}{l}\text { 7. Father's educa- } \\
\text { tion }\end{array}$} \\
\hline \multicolumn{10}{|l|}{$\begin{array}{l}\text { 8. Mother's } \\
\text { education }\end{array}$} \\
\hline $\begin{array}{l}\text { 9. Years of } \\
\text { schooling }\end{array}$ & 1 & & & & & & & & \\
\hline 10. ISEI of first job & $0.516^{* * *}$ & 1 & & & & & & & \\
\hline $\begin{array}{l}\text { 11. ISEl of current } \\
\text { job }\end{array}$ & $0.530^{* * *}$ & $0.671^{* * *}$ & 1 & & & & & & \\
\hline $\begin{array}{l}\text { 12. Self-assess- } \\
\text { ment of health } \\
\text { conditions }\end{array}$ & $0.184^{* * *}$ & $0.105^{* * *}$ & $0.123^{* * *}$ & 1 & & & & & \\
\hline 13. Age & $-0.293^{* * *}$ & $-0.170^{* * *}$ & $-0.217^{* * *}$ & $-0.217^{* * *}$ & 1 & & & & \\
\hline $\begin{array}{l}\text { 14. Father's } \\
\text { household regis- } \\
\text { tration status }\end{array}$ & $0.393^{* * *}$ & $0.284^{* * *}$ & $0.296^{* * *}$ & $0.027^{*}$ & -0.019 & 1 & & & \\
\hline $\begin{array}{l}\text { 15. Mother's } \\
\text { household regis- } \\
\text { tration status }\end{array}$ & $0.388^{* * *}$ & $0.280^{* * *}$ & $0.301^{* * *}$ & $0.038^{* *}$ & $-0.021^{*}$ & $0.871^{* * *}$ & 1 & & \\
\hline 16. Male & $0.193^{* * *}$ & $0.075^{* * *}$ & $0.085^{* * *}$ & $0.117^{* * *}$ & $0.058^{* * *}$ & -0.012 & -0.012 & 1 & \\
\hline 17. Han ethnicity & $0.079^{* * *}$ & $0.063^{* * *}$ & $0.072^{* * *}$ & $0.034^{* *}$ & 0.004 & $0.048^{* * *}$ & $0.042^{* * *}$ & 0.016 & 1 \\
\hline
\end{tabular}

(1) Pearson correlation coefficient is used to measure the correlation between variables.

(2) ${ }^{\#} p<0.1 ;{ }^{*} p<0.05 ;{ }^{* *} p<0.01 ;{ }^{* * *} p<0.001$.

\section{Appendix Table 2: Coefficients of the control variables in the structural equation models}

\begin{tabular}{lllllll}
\hline Variable & $\begin{array}{l}\text { Childhood } \\
\text { nutrition and } \\
\text { hygiene }\end{array}$ & Height & $\begin{array}{l}\text { Years of } \\
\text { schooling }\end{array}$ & ISEI of first job & $\begin{array}{l}\text { ISEl of current } \\
\text { job }\end{array}$ & $\begin{array}{l}\text { Self-assessment } \\
\text { of health } \\
\text { conditions }\end{array}$ \\
\hline Male & $0.015(0.010)$ & $10.465(0.140)^{* * *}$ & $1.618(0.120)^{* * *}$ & $0.605(0.502)$ & $0.367(0.444)$ & $0.036(0.029)$ \\
& {$[0.021]$} & {$[0.662]$} & {$[0.194]$} & {$[0.018]$} & {$[0.010]$} & {$[0.021]$} \\
Female & $-0.001(0.004)$ & $-0.078(0.012)^{* * *}$ & - & - & - & $-0.019(0.001)^{* * * *}$ \\
& {$[-0.021]$} & {$[-0.086]$} & $0.102(0.005)^{* * *}$ & $0.072(0.022)^{* * *}$ & $0.127(0.031)^{* * *}$ & {$[-0.186]$} \\
& & & {$[-0.212]$} & {$[-0.038]$} & {$[-0.062]$} & $0.044(0.037)$ \\
Han ethnicity & $0.067(0.017)^{* * *}$ & $1.558(0.252)^{* * *}$ & $0.753(0.147)^{* * *}$ & $1.590(0.621)^{*}$ & $0.908(0.546)^{*}$ & $0.014]$ \\
& {$[0.053]$} & {$[0.056]$} & {$[0.051]$} & {$[0.027]$} & {$[0.015]$} & {$[0.014]$} \\
\hline
\end{tabular}

(1) Values in the table are unstandardized regression coefficients; values in parenthesis are standard error; values in brackets are standardized regression coefficients.

(2) $\# p<0.1 ;{ }^{*} p<0.05 ;{ }^{* *} p<0.01 ;{ }^{* * *} p<0.001$. 


\section{Abbreviation}

SES: Socioeconomic status.

\section{Acknowledgements}

A preliminary version of the article was presented in the "2016 Winter Forum for Social Stratification and Social Mobility" (Beijing). We want to thank our colleagues who participated in the forum and the anonymous reviewers for their comments and suggestions.

\section{Authors' contributions}

YH designed the study and conducted literature review, data analysis and discussion, and JL contributed in analysis and modeling. Both the authors read and approved the final manuscript.

\section{Funding}

This study was supported by the National Social Science Fund for Young Scholars (Grant No. 17CSH063) and the "Think Tank for the Development of Social Morality."

\section{Availability of data and materials}

Not available. The "Urbanization and Labor Migration Survey" data was collected by Tsinghua University, and it is not currently open to public. Therefore, the authors do not have the right to make the data available to the public.

\section{Declarations}

\section{Competing interests}

The authors declare they have no competing interests.

\section{Author details}

${ }^{1}$ Department of Sociology, School of Humanities, Southeast University, Nanjing, China. ${ }^{2}$ School of Humanities, Southeast University, Jiangning District, Nanjing 211189, Jiangsu Province, China. ${ }^{3}$ Department of Sociology, School of Social Sciences, Tsinghua University, Beijing, China.

Received: 20 May 2021 Accepted: 24 August 2021

Published online: 13 September 2021

\section{References}

Almond, Douglas, and Janet Currie. 2011. Human capital development before age five. In Handbook of labor economics 4 (B), ed. Orley Ashenfelter and David Card, 1315-1486. New York: Elsevier.

Almond, Douglas, Lena Edlund, Hongbin Li, and Junsen Zhang. 2010. Long-term effects of early life development: Evidence from the 1959 to 1961 China famine. In The economic consequences of demographic change in East Asia, ed. Takatoshi Ito and Andrew Rose, 321-345. Chicago: University of Chicago Press.

Almond, Douglas, Janet Currie, and Mariesa Hemann. 2012. From infant to mother: Early disease environment and future maternal health.". Labour Economics 19(4): 475-483.

Basu, Rashmita. 2015. Lasting impacts of childhood health and socioeconomic circumstances on adult health problems: Analysis of a longitudinal count regression model. International Journal of Applied Economics 12(1): 80-97.

Bird, Chloe E., Peter Conrad, Allen M. Fremont, and Stefan Timmermans, eds. 2010. Handbook of medical sociology. Nashville: Vanderbilt University Press.

Black, Sandra E., Paul J. Devereux, and Kjell G. Salvanes. 2007. From the cradle to the labor market? The effect of birth weight on adult outcomes. Quarterly Journal of Economics 122(1): 409-439.

Blau, Peter M., and Otis Dudley Duncan. 1967. The American occupational structure. New York: The Free Press.

Bourdieu, Pierre J., and Jean-Claude Passeron. 2002. The inheritors: French students and their relation to culture. Translated by Xing Kechao. Beijing: Commercial Press. (in Chinese).

Bozzoli, Carlos, Angus Deaton, and Climent Quintana-Domeque. 2009. Adult height and childhood disease. Demography 46(4): 647-669.

Bradley, Robert H., and Robert F. Corwyn. 2002. Socioeconomic status and child development. Annual Review of Psychology 53: 371-399.

Campbell, Frances, Gabriella Contis James, J. Heckman, Seong Hyeok Moon, Rodrigo Pinto, Elizabeth Pungello, and Yi. Pan. 2014. Early childhood investments substantially boost adult health. Science 343(6178): 1478-1485.

Case, Anne, and Christina Paxson. 2008. Stature and status: Height, ability, and labor market outcomes. Journal of Political Economy 116(3): 499-532.

Case, Anne, Darren Lubotsky, and Christina Paxson. 2002. Economic status and health in childhood: The origins of gradient. The American Economic Review 92(5): 1308-1334.

Case, Anne, A. Fertig, and C. Paxson. 2005. The lasting impact of childhood health and circumstance. Journal of Health Economics 24(2): 365-389.

Chen, Edith. 2004. Why socioeconomic status affects the health of children. Current Directions in Psychological Science 13(3): 112-115.

Chen, Guangjin. 2010. Market or non-market? An empirical analysis of the main causes of income inequalities in China today. Sociological Studies 25(6): 86-115 ((in Chinese)).

Chen, Yuyu, and Li.-An. Zhou. 2007. The long-term health and economic consequences of the 1959-1961 famine in China. Journal of Health Economics 26(4): 659-681. 
Chen, Zhuo, David B. Eastwood, and Ziyi Yan. 2006. Nutrition inequality among children in China: Where one lives does matter". World Economic Papers 1: 54-66 ((in Chinese)).

Cheng, Mingwang, Yanhong Jin, Qing'en Gai, and Qinghua Shi. 2014. Focusing on education or health improvement for anti-poverty in rural China: Evidence from national household panel data. Economic Research Journal 49(11): 130-144 ((in Chinese)).

Conti, Gabriella, and James J. Heckman. 2010. Understanding the early origins of the education health gradient. Perspectives on Psychological Science 5(5): 585-605.

Currie, Janet. 2009. Healthy, wealthy, and wise: Socioeconomic status, poor health in childhood, and human capital development. Journal of Economic Literature 47(1): 87-122.

Currie, Janet. 2011. Inequality at birth: Some causes and consequences. American Economic Review 101(3): 1-22.

Currie, Janet, and Joshua Goodman. 2010. Parental socioeconomic status, child heath, and human capital. In International Encyclopedia of Education, ed. Penelope Peterson, Eva Baker, and Barry McGaw, 253-259. Philadelphia, PA: Elsevier.

Currie, Janet, and Enrico Moretti. 2007. Biology as destiny? Short and long-run determinants of intergenerational transmission of birth weight. Journal of Labor Economics 25(2): 231-264.

Currie, Janet, Mark Stabile, Phongsack Manivong, and Leslie L. Roos. 2010. Child health and young adult outcomes. Journal of Human Resources 45(3): 517-548.

Deaton, Angus. 2008. Height, health, and inequality: The distribution of adult heights in India. American Economic Review 98(2): 468-474.

Delaney, Liam, and James P. Smith. 2012. Childhood health: Trends and consequences over the life course. The Future of Children 22(1): 43-63.

Duncan, Greg J., W. Jean Yeung, Jeanne Brooks-Gunn, and Judith R. Smith. 1998. How much does childhood poverty affect the life chances of children? American Sociological Review 63(3): 406-423.

Elder, Glen H. 1999. Children of the great depression: Social change in life experience. New York: Routledge.

Fogel, Robert W. 1994. Economic growth, population theory, and physiology: The bearing of long-term processes on the making of economic policy. The American Economic Review 84(3): 369-395.

Fogel, Robert W., and Nathaniel Grotte. 2011 An overview of the changing body: Health, nutrition, and human development in the western world since 1700. Working Paper 16938, (National Bureau of Economic Research, NBER).

Grossman, Michael. 1972. On the concept of health capital and the demand for health. Journal of Political Economy 80(2): 223-255.

Grossman, Michael. 2008. The relationship between health and schooling. Eastern Economic Journal 34(3): 281-292.

Gundersen, Craig, and Brent Kreider. 2009. Bounding the effects of food insecurity on children's health outcomes. Journal of Health Economics 28(5): 971-983.

Haas, Steven A. 2006. Health selection and the process of social stratification: The effect of childhood health on socioeconomic attainment. Journal of Health and Social Behavior 47(4): 339-354.

Haas, Steven A. 2008. Trajectories of functional health: The "long arm" of childhood health and socioeconomic factors. Social Science \& Medicine 66(4): 849-861.

Haas, S.A., M.M. Glymour, and F. Berkman. 2011. Childhood health and labor market inequality over the life course. Journal of Health and Social Behavior 52(3): 298-313.

Habicht, Jean Pierre, Reynaldo Martorell, and Juan A. Rivera. 1995. Nutritional impact of supplementation in the INCAP longitudinal study: Analytical strategies and influences. Journal of Nutrition 125(4S): 1042S-1050S.

Hannum, Emily, and Yuping Zhang. 2012. Poverty and proximate barriers to learning: Vision deficiencies, vision correction, and educational outcomes in rural northwest China. World Development 40(9): 1921-1931.

Hao, Dahai. 2007. A study of educational disparity in urban China: 1949-2003. Social Sciences in China 6: 94-107 ((in Chinese)).

He, Qing, and Yan Yuan. 2014. The intertemporal effect of childhood health and nutrition status on adulthood income. Economic Review 2: 52-64 ((in Chinese)).

Heckman, James J. 2007. The economics, technology, and neuroscience of human capability formation. Proceedings of the National Academy of Sciences of the United States of America 104(33): 13250-13255.

Hong, Yanbi, and Yunsong Chen. 2017. Group differences of education effects on health: Resources substitution and disadvantage reinforcement, 2005-2012. Journal of Social Development 4(1): 1-18 ((in Chinese)).

Hout, Michael. 2015. A summary of what we know about social mobility. Annals of the American Academy of Political and Social Science 657(1): 27-36.

$\mathrm{Hu}$, Anning. 2014. Can education make us healthier? A comparative analysis of urban and rural areas based on the Chinese General Social Survey for 2010. Social Science in China 5: 116-130 ((in Chinese)).

Hu, Wen, Hao Zhang, Yi. Li, Shiding Liu, and Guang Guo. 2012. The influence of molecular genetics on sociology. Sociological Studies 27(5): 224-241 ((in Chinese)).

Jamison, Dean T. 1986. Child malnutrition and school performance in China. Journal of Development Economics 20(2): 299-309.

Jiao, Kaishan. 2014. Health inequalities of different socio-economic status and its influencing factors. Sociological Studies 29(5): 24-46 ((in Chinese)).

Kim, Younoh, Bondan Sikoki, John Strauss, and Firman Witoelar. 2015. Intergenerational correlation of health among older adults: Empirical evidence from Indonesia. Journal of the Economics of Ageing 6: 44-56.

Le, Huong, and Ha Nguyen. 2015. Intergenerational transmission in health: causal estimates from fixed effects instrumental variables models for two cohorts of Australian children. Working Paper 68175, (Munich Personal RePEc Archive, MPRA).

Li, Chunling. 2014. Educational experience and inequality of opportunity among the post-80s generation- with comments on The Silent Revolution. Social Sciences in China 4: 66-77 ((in Chinese)).

Li, Lulu, and Bin Zhu. 2015. Changes in the pattern of intergenerational mobility in contemporary China. Social Sciences in China 5: 40-58 ((in Chinese)).

Liang, Haixiang. 2017. Health inequality among adolescents and young adults in China: mechanism and consequences. Doctoral dissertation, School of Social and Behavioral Sciences, Nanjing University (in Chinese). 
Liu, Xin. 2018. Coordination, domination and income distribution: The structure of social stratification in transitional China. Sociological Studies 33(1): 89-115 ((in Chinese)).

Liu, Airan, and Yu. Xie. 2015. Influences of monetary and non-monetary family resources on children's development in verbal ability in China. Research in Social Stratification and Mobility 40: 59-70.

Lundborg, Petter, Anton Nilsson, and Dan-Olof. Rooth. 2014. Adolescent health and adult labor market outcomes. Journal of Health Economics 37: 253-278.

Luo, Renfu, Yaojiang Shi, Huan Zhou, Ai. Yue, Linxiu Zhang, Sean Sylvia, Alexis Medina, and Scott Rozelle. 2015. Micronutrient deficiencies and developmental delays among infants: evidence from a cross-sectional survey in rural China. British Medical Journal Open 5: e008400.

Lutter, Chessa K., Jean-Pierre. Habicht, Juan A. Rivera, and Reynaldo Martorell. 1992. The relationship between energy intake and diarrhoeal disease in their effects on child growth: Biological model, evidence, and implications for public health policy. Food and Nutrition Bulletin 14(1): 36-42.

Maher, Brendan. 2008. Personal genomes: The case of the missing heritability. Nature 456: 18-21.

Maluccio, John A., John F. Hoddinott, Jere R. Behrman, Reynaldo Martorell, and Agnes R. Quisumbing. 2006. The impact of nutrition during early childhood on education among Guatemalan adults. Working Paper of Population Studies Center, University of Pennsylvania. 06-04.

Marmot, Michael. 2004. The Status Syndrome: How Social Standing Affects Our Health and Longevity. New York: Henry Holt.

Nielsen, Francois, and J. Micah Roos. 2015. Genetics of educational attainment and the persistence of privilege at the turn of the 21st century. Social Forces 94(2): 535-561.

Noble, Kimberly G., Suzanne M. Houston, Natalie H. Brito, et al. 2015. Family income, parental education and brain structure in children and adolescents. Nature Neuroscience 18: 773-778.

Pakpahan, Eduwin, Rasmus Hoffman, and Hannes Kroger. 2017. The long arm of childhood circumstances on health old age: Evidence from SHARELIFE. Advance in Life Course Research 31: 1-10.

Palloni, Alberto. 2006. Reproducing inequalities: Luck, wallets, and the enduring effects of childhood health. Demography 43(4): 587-615.

Palloni, Alberto, and Carolina Milesi. 2006. Economic achievement, inequalities and health disparities: The intervening role of early health status. Research in Social Stratification and Mobility 24(1): 21-40.

Power, Chris, Ken Fogelman, and John Fox. 1986. Health and social mobility during the early years of life. Quarterly Journal of Social Affairs 2(4): 397-413.

Qi, Yaqiang. 2014. Reliability and validity of self-rated general health". Chinese Journal of Sociology 34(6): 196-215 ((in Chinese)).

Ross, Catherine E., and John Mirowsky. 2010. Why education is the key to socioeconomic differentials in health. In Handbook of Medical Sociology, ed. C. Bird, P. Conrad, A. Fremont, and S. Timmermans, 33-51. Nashville: Vanderbilt University Press.

Santrock, John 2009, Life-Span Development. Translated by Sang Biao et al. Shanghai: Shanghai People's Press (in Chinese).

Schultz, Theodore W. 1961. Investment in human capital. The American Economic Review 51(1): 1-17.

Sewell, William H., Robert M. Hauser, Kristen W. Springer, and Taissa S. Hauser. 2001. As we age: the Wisconsin Longitudinal Study, 1957-2001. CDE Working Paper of Department of Sociology, University of Wisconsin-Madison, 2001-2009.

Shen, Tiefu, Jean-Pierre. Habicht, and Ying Chang. 1996. Effect of economic reforms on child growth in urban and rural areas of China. New England Journal of Medicine 335(6): 400-406.

Smith, Patricia K., and W. Jean Yeung. 1998. Childhood welfare receipt and the implications of welfare reform. Social Service Review 72(1): 1-16

Smith, James P., Yan Shen, John Strauss, Yang Zhe, and Yaohui Zhao. 2012. The effects of childhood health on adult health and SES in China. Economic Development and Cultural Change 61(1): 127-156.

Strauss, John, and Duncan Thomas. 1998. Health, nutrition, and economic development. Journal of Economic Literature 36(2): 766-817.

Sun, Qixiang, and Xiaobo Peng. 2014. Review on health inequality, early-life environment and intergenerational transmission of health human capital. Social Sciences in Chinese Higher Education Institutions 1: 133-143 ((in Chinese)).

Tang, Junchao. 2015. Lost at the starting line: A reconsideration on educational inequality in China (1978-2008). Sociological Studies 30(3): 123-145 ((in Chinese)).

Treiman, Donald J., and Kam-bor Yip. 1989. Educational and occupational attainment in 21 countries. In Cross-National Research in Sociology, ed. Melvin L. Kohn, 373-394. Beverly Hills: Sage.

Wang, Fuqin. 2011. Does social mobility contribute to reduce the inequality of health? Sociological Studies 25(2): 78-101 ((in Chinese)).

Wang, Fuqin. 2012. Socioeconomic status, lifestyle and health inequality. Chinese Journal of Sociology 32(2): 125-143 ((in Chinese)).

Wang, Fuqin. 2017. Intergenerational social mobility and mental health. Journal of Social Development 4(1): 42-55 ((in Chinese)).

Wang, Aiqin, Alexis Medina, Renfu Luo, Yaojiang Shi, and Ai. Yue. 2016. To board or not to board: Evidence from nutrition, health and education outcomes of students in rural China.". China \& World Economy 24(3): 52-66.

Warren, John Robert. 2009. Socioeconomic status and health across the life course: A test of the social causation health selection hypotheses. Social Forces 87(4): 2125-2153.

Wu, Minglong. 2010. Structural Equation Model: AMOS Operation and Application. Chongqing: Chongqing University Press ((in Chinese)).

Wu, Yuxiao. 2013. The keypoint school system, tracking, and educational stratification in China: 1978-2008. Sociological Studies 28(4): 179-202 ((in Chinese))

Wu, Kin Bing. 2011. Early childhood development and education in China: breaking the cycle of poverty and improving future competitiveness. World Bank, Report No. 53746-CN. 
Xu, Duoduo. 2017. From poverty to prosperity: Poverty, non-cognitive abilities, and first-job earnings. Chinese Journal of Sociology 37(4): 90-118 ((in Chinese))

Yue, Ai, Lauren Marsh, Huan Zhou, Alexis Medina, Renfu Luo, Yaojiang Shi, Linxiu Zhang, Kaleigh Kenny, and Scott Ro. 2016. Nutritional deficiencies, the absence of information and caregiver shortcomings: a qualitative analysis of infant feeding practices in rural China. PLoS ONE 11(4): e0153385.

Zhou, Yi. 2009. After Blau-Duncan status attainment model: Transmutations or challenges? Sociological Studies 24(6): 206-225 ((in Chinese)).

Zou, Xiaojin, Rongliang Qiu, Xiaoyong Zhou, and Wenhui Zheng. 2008. Heavy metal contamination and health risk assessment in Dabao Mountain, China. Acta Scientiae Circumstantiae 7: 1406-1412 ((in Chinese)).

\section{Publisher's Note}

Springer Nature remains neutral with regard to jurisdictional claims in published maps and institutional affiliations.

Submit your manuscript to a SpringerOpen ${ }^{0}$ journal and benefit from:

- Convenient online submission

- Rigorous peer review

- Open access: articles freely available online

- High visibility within the field

- Retaining the copyright to your article

Submit your next manuscript at $\gg$ springeropen.com 